\title{
Political Discourse Analysis of Jokowi vs Prabowo Subiyanto Speeches in the First Presidential Election Debate: Critical Thinking Perspectives
}

\author{
Sudar \\ \{rofiqsdr@gmail.com\} \\ Universitas Muhammadiyah Purworejo, KH.A.Dahlan Street No.3 \\ Purworejo.54111.Tel/Faxs.0275321494, Central Java, Indonesia.
}

\begin{abstract}
This paper aims to discuss the issues of political news that happened in our country, and it is hot -news that was recently conducted by the Indonesian Government. It is the general election of the President. In the process of the Presidential Election, there is a crucial process, and it is the debate that is conducted five times, from the first and the last session. In this paper, the writer would like to discuss the speeches spoken by Jokowi and Prabowo. The first debate was conducted on January 18, 2019. It was the period that really waited for society, how Jokowi and Prabowo debated each other. It is necessary to know what kinds of speeches they used to argue both of them to talk about political life in Indonesia. It can be used as a material of reading skills from critical thinking perspectives.
\end{abstract}

Keywords: Political Discourse, Speeches, Critical Thinking, Presidential Candidate, Election.

\section{Introduction}

Understanding the speeches based on the context of situation and culture is necessary to be developed among the language learners. This skill is concerning to the language learners, how and why they should understand the speeches spoken by other speakers in different contexts. Further, the writer would like to discuss and share how to dig up the speeches spoken by certain people in a particular context from the political discourse analysis. It is identified specifically about the speech that commonly contains the speaker's intent and to understand the public's ideas. [1] Political speech commonly contains the speaker's intent to catch the public's attention. The contents of the speech, such as; the speaker's purposes, the importance of the speech, and it is usually accompanied by a photo, picture, statistic, related to the topic of speech. . [2]Political Discourse Analysis (PDA) is a kind of knowledge that inter-and multidisciplinary. [3] political discourse (PD) is speeches that perform both formal and non-formal concerning politics. Furthermore, Banhegyi, Matyas mentioned there are three components of political contents, namely; text, power and ideology. 


\section{Literatur Review}

Text represents the actions of a person or group of people in both formal and non-formal speeches. Further, power is the human of maintaining and obtaining the contents of communication. Then, Ideology is the basic belief which is underlined in the representations of individuals or a social group. Furthermore, [4] politics and language have intimate links at the fundamental level.Further, Chilton described that politics can be defined in the micro and macro view. In the Micro level, politics is a variety of techniques for distributing the persuasion, sharing rational arguments, and talking about irrational strategies done to get the purposes of politics itself. Then, political activities will not exist without using a language. Knowing the language used in the term of politics is necessary. It is needed to understand the language used critically. What is meant by critical thinking skill? [5] Critical thinking is an intellectual activity that needs to be active and fluent to conceptualize. Further, [6] critical thinking is a critical education that students should be responsible and have a good attitude. [7]. Critical thinking is defined as knowledge that can be influential in almost every discipline life.

It is associated with the abilities for problem-solving and decision-making.[8] Critical thinking is necessary for students, educators, and other professions in the field of education. It is because based on their research results' stated that most students in South -East Asia, including Indonesia are considered lacking critical thinking skills. This is a fact that analyzing the Jokowi versus Prabowo's speeches is necessary as an alternative material for reading skill identified from critical thinking perspectives.[9]Critical thinking is how to think critically and responsible acts that they have done.

\section{Method}

This is a qualitative descriptive study, particularly it is conducted from political discourse theory. To analyze the data the writer used the theory of qualitative data analysis.

\subsection{The data of research}

The object of the research is the transcripts of Jokowi and Prabowo Subiyanto speeches in the first Session of President Election Debate. The transcription of the Jokowi and Prabowo Subiyanto Speeches spoken in the $18^{\text {st }}$ January 2018.

\subsection{Data Analysis}

The Steps of analyzing the data are as follows: the first, reduction the data, it means that in the process of analyzing the data, it is needed to select, to be focused, to simplify and to be an abstract form of transcription. The second, displaying the data, means that the data can be displayed in the form of diagram, chart, or matrix to describe the data. The third, conclusion and verification, means by stepping back to the consideration of what is going to be analyzed and to assess the implication[11]. There are three steps of analyzing the qualitative data, such as; reduction of the text, exploration of the text, and integration of the exploration. 


\section{Result and Discussion}

The data of this study is taken from Jokowi and Prabowo speeches in their first presidential debate conducted on Friday, January 18, 2019. It is written by Jakarta Post. The data is as follows. The first issue is about the President is the chief law enforcement officer. Here is the dialogue between Jokowi and Prabowo about the first issue. "Prabowo said; I would like to empower the national law agencies by involving legal experts to help synchronize national law and local ordinances. Then, Jokowi said; I would place all legislative functions of ministries under the National Legislation Center, directly under the President, to address the issue. Further, Prabowo responded; it was the Government's responsibility to synchronize and create regulations. Then, Prabowo said; President is the chief law enforcement officer, and he is responsible for the implementation of law enforcement" (Jakarta Post).

The first key moment is about law enforcement. Prabowo would like to synchronize between national law and local ordinates. While Jokowi would like to place the legislative function of ministries under National Legislation, directly under the President. Interpreting Jokowi statement, it meant that Jokowi is more powerful, by saying that the law enforcement directly coordinated by the President at the last decision, even the previous process done by the ministries under the National Legislations. Further, Jokowi chose the powerful, significant, and measurable dictions of words. The second key moment was about the corruption that happened in Indonesia. Here is the dialogue between Jokowi and Prabowo. "Jokowi stated; I would like to strengthen the supervision and would like to create transparency for conducting the recruitment process to the civil servants to solve the corruption problem.

Prabowo and Sandiaga said; they would like to resolve the root causes of corruption by increasing the salaries of civil servants and law enforcers to prevent corruption. Further, Jokowi responded to Prabowo and Sandiaga, Jokowi said, I disagree. Then, Jokowi mentioned his reasons that the salaries of Indonesia's civil servants is sufficient, since they also receive performance allowances. Jokowi stressed that it is better to strengthen the supervision, by involving the media and the State Civilian Bureaucracy Commission (KASN) to create a clean government and it is free from corruption". (Jakarta Post). The second key moment is about the curb of corruption. Jokowi would like to strengthen the supervision and the transparency of the recruitment process. While Prabowo prefers to increase the salaries of civil servants.

Then, Jokowi replied to Prabowo argumentation, Jokowi disagreed to curb the corruption by increasing the civil servant's salaries. Jokowi said that the civil servants' salaries are enough to curb the corruption by doing better supervision including by the media and strengthening the Corruption Eradication Commission (KPK) to combat the corruption. It is again that Jokowi used fact strategies to answer the questions related to combating corruption in Indonesia. Further, Jokowi argued that a high salary is not a guarantee to save the government officers from corruption. Jokowi's arguments are that by doing better supervision and strengthening the KPK are the key to combat corruption. It meant that Jokowi used the facts and logic and measurement answers. The third key moment, it was about the spaces that Jokowi stopped not giving the response to the Prabowo argumentations.

In this session, "Jokowi said I have nothing to add". (Jakarta Post). Here, Jokowi to save himself from the Prabowo argumentation, he would like to say I have nothing to add. This is a safe answer rather than to answer the questions that no need more explanation about "law enforcement, human right, and corruption combating. He thought that his answers were enough and carefully to answer the questions. At the fourth key moment, Jokowi and Prabowo created speeches about the corruption combating. Further, the fourth key moment is still about corruption combating. The dialogue between Jokowi and Prabaow is the follows; "Jokowi said 
to Prabowo: the Gerindra Party had nominated at least six former graft convicts as candidates in the legislative election, it is taken from the citing of Indonesia Corruption Watch (ICW) data.

Then Prabowo said that the ICW report was very subjective, and Prabowo argued that his party was free from corrupt practices. Then, Prabowo stated, I would send party members who committed corruption to jail. Furthermore, Jokowi responded; there are six ex-graft convicts that you have nominated as legislative candidates. The nomination is signed by the party chairman and secretary-general, which means that you have signed" (Jakarta Post). In the fourth key moment of presidential debate, Jokowi really gave the direct jab to Prabowo. It makes Prabowo really get a deep jab from Jokowi, and it makes Prabowo get high triggers, that is the fact by massaging Praowo's shoulders to decrease Prabowo's triggers and Prabowo himself a bit of a dance to make himself calm. Furthermore, at the fifth key moment, Jokowi and Prabowo spoke their speeches about gender.

The dialogue between Jokowi and Prabowo is as the follows; "Jokowi said: the executive board of Gerindra was dominated by males. Prabowo said to Jokowi; the party had a woman deputy chairperson as well as a women's wing. Our strongest supporters are also mothers. Jokowi responded to the Prabowo statement: my cabinet has nine women serving as my aides in ministerial seats. Prabowo argued; female ministers had issued policies that did more harm than good. Then Prabowo said to Jokowi; you should not be proud of appointing women if the programs had not benefited the people. Further, Prabowo said that Gender should not be the main concern" (Jakarta Post). The fifth key moment is about the gender issue. Jokowi asked Prabowo, that Gerindra was mostly dominated by males. Prabowo argued that Gerindra also has the woman deputy, and the party was supported by the mothers.

Jokowi stated that his cabinet has nine woman ministries. It is the answer to Prabowo. Again, Jokowi gets a factual and measurable answer to argue Prabowo's statement in the public's audiences. It meant that Jokowi is more powerful than Prabowo in terms of politics. At the sixth key moment, Jokowi and Prabowo developed their utterances about their supporters. "Prabowo said to Jokowi; law enforcers politically bias because a number of regional leaders who had openly thrown support behind Jokowi-Ma'ruf were free from scrutiny; but a village head in Mojokerto, East Java, was sent to jail after he had declared support for my Party. It violated human rights, particularly freedom of expression. Then Jokowi answered Prabowo's statement; Jokowi said; don't accuse us, Pak Prabowo.

Further, Jokowi said to Prabowo, We are a country with rule of law, so there is a legal mechanism that we can adhere to. If Pak Prabowo has any evidence, just report it to the [police]" (Jakarta Post). In the sixth key moment, Prabowo described that a number of regional leaders, (Governor) openly had supported Jokowi-Ma'ruf but this phenomena was free from scrutiny. It meant that the regional leaders who supported Jokowi-Ma'ruf are free to express their support. On the contrary a head of the village in Mojokerto who supported Prabowo-Sandi was sent to the jail. In this case, Jokowi replied to Prabowo, powerfully and accurately stating' if you (Prabowo) have any evidence, just report it to the police. We are a country with rule of Law, there is a legal mechanism that we can adhere to.

Jokowi responds to make Prabowo think based on the fact, but Jokowi is more powerful, he lets Prabowo report the case to the police, if Prabowo has any evidence. It meant that Jokowi (incumbent) candidate is really powerful. He was able to organize the regional leaders to support him, and it was free from the scrutiny. It reflected that Jokowi was more powerful in relation to organizing their supporters systematically. Further, Prabowo argued that one of the head of the village declared to support Prabowo and Sandi, Prabowo said that the head village was reported to the police and he was sent to jail. Jokowi, replied, if you (Prabowo) has the data, Jokowi let him to report to the police, it is as a fact that we are in a country of law, Jokowi said.in this case, 
Jokowi also really so his powerfulness to jab the Prabowo's statement.Then, at the seventh key moment.

It was about human rights. The statement of the seventh key moments is as follows;'Jokowi said that I still committed to resolving the cases. There was no such thing mentioned in your own visions. Jokowi said that it is a report from the military documents, it is in 2014, and it showed that the Indonesian Military's (TNI) officer's ethics council had discharged Prabowo for his involvement in the forced disappearances. In Jokowi's closing statement, Jokowi said to Pak Prabowo; we won't talk too much, we understand the nation's problems and what we have to do to address them. Then Jokowi said frankly; we are not dictators or authoritarians. Furthermore, Jokowi said seriously, we do not have a track record of human rights violations, violence or corruption" (Jakarta Post).

The seventh key moment is about human rights. In this case, Jokowi stated frankly, it meant that Prabowo didn't mention this issue in his vision. Further, Jokowi added his statement accompanied by the data, Jokowi said that Indonesian Millitary's Officer Ethics has a note that Prabowo had been discharged from TNI, it is because his involvement in the force disappearances, Jokowi stated frankly. Further, in the last statement, Jokowi really gives a deep and factual jab to Prabowo. In the closing statement, Jokowi deeply shows his powerfulness, even though he said seriously, he is still tolerant not to use the pronoun "I" he used the pronoun"we". It meant that Jokowi was not alone. He was supported by the real partners, he was Prof.Dr.K.H. Ma'ruf Amin. The use of the pronoun "we" really shows his powerfulness including the involvements of his vice-president candidate and his supporters.

\section{Conclusion}

Related to the data analysis, it is really significant that critical thinking skills are needed by students and any language learners. In this paper, the writer is able to take some meaningful values of critical thinking skills particularly related to the speeches spoken by Jokowi and Prabowo in the first presidential debate. In the seven key moments of the first presidential debates, it shown that the language used by Jokowi is more powerful than Prabowo speeches, even Prabowo gave and argued some Jokowi statements, on the contrary Jokowi gave the deep and factual jabs to Prabowo.

The Jokowi's jabs given to Prabowo mostly in the every seven key moments. Further, the deepest and the strongest jab was the statement concerning the human rights violations and corruption. Jokowi said that he and his vice-president candidate, his supporters are not dictators, not authoritarian and we don't have a track record of human rights violations, and no corruption. This statement was supported by the data from the of Military's Officer Ethics, about the Prabowo involvements of the force of disappearances. That is one of the facts that, in the following debate Jokowi Ma'ruf was able to smoothly do the debates among them. Further, from the seven key moments of the first presidential debate, it was clear that Jokowi-Ma'ruf is the President and vice-president candidate that shows their performances more powerful than the rivals. Then critical thinking is usable to be implemented in any reading skills, one of examples is Jokowi versus Prabowo speeches written in the Jakarta Post, January 18, 2019. 
Acknowledgments. The author would like to thank Purworejo Muhammadiyah University, The Rector who has facilitated the process of conducting research and also the Dean of Education and Teacher Training who facilitated my article in the conference. Hopefully, this article will be valuable to all the following researchers.

\section{References}

[1] Oana, Bianca.:A Brief Analysis of the Political Discourse. https:en.org./wiki/Politics.Factors Enhancing Communication,or What (Not) to Do When Speaking in Public. Vol. CCI 3. Petru Mainor" University Publishing, T Mures, Romania,. http://www.upm.ro.cci3/. (2014)

[2] Dunmire, Patricia.: Political Discourse Analysis: Exploring the Language of Politics and the Politics of Language. Language and Linguistics Compass. Blackwell Publishing, Ltd.(2012)

[3] Banhegyi, Matyas.2014.Translation and Political Discourse. Acta University Sapientiae, Philologica, 139-158. (2014)

[4] Chilton, Paul.: Analyzing Political Discourse. Routledge, 11 New Fetter, Lane. London EC4P, 4EE.( 2004)

[5] Yousefi, Soraya and Mohammadi, Mojtaba.: Critical Thinking and Reading Comprehension Among Postgraduate Students: The Case of Gender and Language Proficiency Level. Journal of Language Teaching and Research, Vol.7, No 4, pp.802-807, July , DOI:http://dx.doi.org/10.17507/jltr.0704.23.(2016)

[6] Wilson, Kate.: Critical Reading, Critical Thinking: Delicate scaffolding in English for Academic Purposes (EAP). Elsevier Ltd: Thinking Skills and Creativity in Second Language Education. University of Technology, Sydney, PO Box 123, Broadway, NSW, Australia. http://dx.doi.org/10.1016/j.tsc.2016.10.002. (2016)

[7] Vaseghi,Reza and Barjesteh,Hamed.:Critical Thinking: A Reading Strategy in Developing English Reading Comprehension Performance. Sheikhbahaee EFL Journal, Vol 1, No.2, August,(2012)

[8] Dewi,A Pranita, Musthafa B, and Gustine.: Using Cooperative Learning in Teaching Critical Thinking in Reading. Journal of English Education, Vol, 4 Issue 1, December, 2015. https://journal.uniku.ac.id/index.php/ ERJEE.

[9] Haryati and Hidayati.:Hoax News: Promoting the Students' Critical Thinking in Critical Reading Class.Register Journal.pp.122-139.p-ISSN: 1979-8903;e-ISSN:250340X.http://journalregister.iainsalatiga.ac.id/index.php/register.Vol.10,No.2,(2017),

[10] ]Miles \& Huberman.:1994. Qualitative Data Analysis. Sage Publications, Inc. 2455 Teller Road, Thousand Oaks, California 91320.E-mail:order@sagepub.com, (1994).

[11] Khan, Tareef Hayat.:Step by step Approach for qualitative data Analysis. International Journal of Built Environment and Sustainability. Faculty of Built Environment, Universiti Teknologi Malaysia. http://www.ijbes.utm.my IJBES 5(3) 2018, 163-174.( 2018) 